\title{
Ocena prawdopodobieństwa klinicznej skuteczności terapii empirycznej zakażeń grzybiczych błony śluzowej jamy ustnej
}

\author{
Assessment of the clinical effectiveness probability \\ for the empiric therapy of oral fungal infections
}

Katedra i Zakład Periodontologii i Chorób Błony Śluzowej Jamy Ustnej, Gdański Uniwersytet Medyczny

DOI: http://dx.doi.org/10.20883/df.2017.1

\section{Streszczenie}

Wstęp. Infekcje powodowane przez grzyby drożdżopodobne należą do najczęstszych schorzeń błony śluzowej jamy ustnej. Przeciwgrzybicza terapia celowana, poprzedzona oznaczeniem antymykogramu, jest najbardziej pożądana. Jednak w wielu sytuacjach klinicznych ordynowana jest terapia empiryczna - wyboru leku dokonuje się na podstawie dostępnych publikacji dotyczących prawdopodobnej lekooporności patogenów.

Cel. Celem pracy było oszacowanie prawdopodobieństwa klinicznej skuteczności empirycznej terapii zakażeń grzybiczych błony śluzowej jamy ustnej na podstawie analizy profilu lekooporności wyizolowanych szczepów grzybów drożdżopodobnych.

Materiał i metody. Materiał badawczy stanowiło 197 pacjentów Katedry i Zakładu Periodontologii i Chorób Błony Śluzowej Jamy Ustnej Gdańskiego Uniwersytetu Medycznego. Analizowano wyniki hodowlanych badań mikologicznych, wykonywanych rutynowo w algorytmie diagnostyczno-leczniczym zakażeń grzybiczych jamy ustnej. Oznaczano lekowrażliwość dla 7 leków: nystatyny, amfoterycyny B, flukonazolu, mikonazolu, ketokonazolu, itrakonazolu oraz flucytozyny. Uwzględniając przypadki multiinfekcji, oszacowano prawdopodobieństwo klinicznej skuteczności przeciwgrzybiczej terapii empirycznej w badanej grupie chorych oraz w 3 podgrupach, wydzielonych wg wieku.

Wyniki i wnioski. W badanej grupie wyizolowano łącznie 223 szczepy grzybów drożdżopodobnych. Najczęściej izolowane szczepy Candida albicans charakteryzowały się najwyższą lekowrażliwością wobec testowanych leków. Szczepy Geotrichum candidum oraz Candida tropicalis także wykazywały niską lekooporność. Najwyższą lekooporność obserwowano wśród szczepów Candida guilliermondii, krusei oraz glabrata. Amfoterycyna B oraz nystatyna charakteryzowały się najwyższym prawdopodobieństwem klinicznej skuteczności w terapii empirycznej, jeśli wziąć pod uwagę ogół zidentyfikowanych patogenów. Pochodne azolowe oceniono jako mniej przewidywalne w terapii empirycznej. Ryzyko nieskuteczności terapii empirycznej wzrasta w podgrupie chorych powyżej 60 roku życia.

Słowa kluczowe: grzyby drożdżopodobne, Candida spp., kandydoza błony śluzowej jamy ustnej, lekooporność grzybów, lekowrażliwość grzybów.

\begin{abstract}
Introduction. Infections caused by yeast-like fungi are some of the most common oral mucosa diseases. Targeted therapy, following antifungal susceptibility tests, is the most beneficial course. But in some clinical situations where empiric therapy is administered, the appropriate antifungal agent must be chosen based on published data about expected pathogens' resistance. Aim. The aim of the study was an assessment of the clinical effectiveness probability for the empiric therapy of oral mucosa candidosis, based on the antifungal resistance profile of isolated yeast-like strains.

Material and methods. The research material consisted of 197 patients from the Department of Periodontology and Oral Mucosa Diseases, Medical University of Gdańsk, Poland. The results of mycological cultures, used in routine clinical diagnostic and treatment algorithms for oral cavity fungal infections, were analyzed. Sensitivity tests for 7 antifungal drugs (nystatin, amphotericin B, fluconazole, miconazole, ketoconazole, itraconazole and flucytosine) were performed. Including multi-infection cases, the clinical efficacy probabilities of empirically administered antifungal agents were evaluated in the whole group and in 3 subgroups, assigned according to age.

Results and conclusions. In studied group a total of 223 strains of yeast-like fungi were isolated. The most often isolated Candida albicans had the highest susceptibility to all the tested antifungal drugs. The Geotrichum candidum and Candida tropicalis strains also had low resistance to the tested antifungal agents. The highest antifungal resistance was observed among the Candida guilliermondii, krusei and glabrata species. Amphotericin B and nystatin were characterized by the highest probability of clinical efficacy, considering all the isolated yeast-like fungi, while the azole derivatives were evaluated as less predictable in terms of empirical administration. The empiric therapy ineffectiveness risk increased in the subgroup of patients aged over 60.
\end{abstract}

Keywords: yeast-like fungi, Candida spp., oral candidosis, antifungal resistance, antifungal susceptibility.

\section{Wstęp}

Infekcje związane z grzybami drożdżopodobnymi należą do najczęstszych schorzeń błony śluzo- wej jamy ustnej. W ciągu ostatnich lat częstość ich występowania wzrasta, a głównym czynnikiem etiologicznym są grzyby z rodzaju Candi- 
da [1-3]. Różnorodne gatunki grzybów Candida stanowią część komensalnej mikroflory j. ustnej u około $50-75 \%$ populacji, wśród ludzi młodych w Polsce izolowane są w około $40 \%$ przypadków $[4,5]$. Grzybica błony śluzowej j. ustnej ma wiele cech infekcji oportunistycznej - wzrost częstości zakażeń jest związany z czynnikami predysponującymi, naruszającymi ekologiczną równowagę w j. ustnej. Candidosis jest powszechną patologią błony śluzowej wśród pacjentów z niedoborami odporności - np. pacjentów zakażonych HIV lub poddawanych terapii immunosupresyjnej bądź chemioterapii. Jest także częstym powikłaniem szerokospektralnej antybiotykoterapii. Najistotniejsze miejscowe czynniki ryzyka candidosis związane są z użytkowaniem ruchomych uzupełnień protetycznych, w szczególności w powiązaniu z niedostateczną higieną jamy ustnej i protez - kandydoza błony śluzowej j. ustnej należy do najczęstszych stomatopatii protetycznych [3]. Ważnym czynnikiem predysponującym jest kserostomia - w najgroźniejszej formie występująca jako objaw uboczny radioterapii oraz objaw schorzeń o etiologii autoimmunologicznej, np. zespołu Sjögrena [1, 6]. Kliniczne podejrzenie zakażenia grzybiczego powinno zostać potwierdzone jedną z dostępnych metod identyfikacji mikologicznej, wśród których wyróżniamy: bezpośrednią identyfikację mikroskopową (metoda o znaczeniu głównie historycznym), posiew i hodowle na odpowiednich podłożach (metoda klasyczna, stanowiąca „złoty standard"), testy serologiczne oraz testy molekularno-biologiczne (identyfikujące wskaźnikowe sekwencje materiału genetycznego grzybów) [7, 8]. Dostępność diagnostyki mikologicznej należy uznać za dobrą - mimo to nierzadko rozpoznanie oparte jest wyłącznie na badaniu klinicznym, co może prowadzić do pomyłek diagnostycznych i niewłaściwego ukierunkowania terapii. W złożonym procesie leczenia kandydozy dobór leku przeciwgrzybicznego ma kluczowe znaczenie. Powinien on bazować na analizie profilu lekowrażliwości zidentyfikowanego patogenu. Jednak stosunkowo często w praktyce klinicznej zdarzają się przypadki, gdy lekarz nie dysponuje antymykogramem i nie może zlecić terapii celowanej. Wśród potencjalnych przyczyn takich sytuacji należy przede wszystkim wskazać użycie metod badania mikologicznego bez technicznej możliwości analizy lekooporności patogenu - np. testów immunologicznych lub testów molekularno-biologicznych, identyfikujących DNA grzybów. W niektórych przypadkach istnieje kliniczna potrzeba natychmiastowego wdrożenia terapii przeciwgrzybiczej, przy braku czasu potrzebnego na względnie czasochłonne testy lekowrażliwości. Inne przyczyny braku antymykogramu to względy ekonomiczne lub brak dostępności odpowiedniego laboratorium diagnostycznego. W w/w sytuacjach klinicysta staje przed problemem wyboru empirycznej terapii przeciwgrzybiczej - bazując na publikowanych wytycznych terapeutycznych. Dane publikowane w ostatniej dekadzie wskazują na znaczące zróżnicowanie $w$ rozpowszechnieniu gatunków patogennych grzybów oraz ich lekooporności w wielu krajach. Długoterminowe obserwacje epidemiologiczne w Europie oraz w USA wskazały na fakt rosnącej częstości infekcji wywołanych przez inne gatunki grzybów niż najpowszechniej spotykany Candida albicans, w tym gatunki o istotnie wyższej lekooporności [2, 4, 9-11]. W ostatnich latach wdrożono do praktyki klinicznej szereg nowych leków przeciwgrzybiczych, np. nowe pochodne triazolowe: worykonazol i posakonazol, a także echinokandyny. Jednakże są to preparaty kosztowne, w większości rezerwowane dla lecznictwa zamkniętego w przypadku inwazyjnych grzybic układowych. Nie grają one ważniejszej roli w rutynowym leczeniu ambulatoryjnym i nie są realną alternatywą dla „starych” antymykotyków. Tym samym monitorowanie rozpowszechnienia patogenów grzybiczych oraz trendów ich lekooporności jest wciąż aktualnym zagadnieniem z perspektywy stomatologa praktyka. W przypadku decyzji o przeciwgrzybiczej terapii empirycznej analiza takich danych ułatwia dobór leku o największym prawdopodobieństwie skuteczności [7, 12, 13].

\section{Cel}

Celem pracy była próba oszacowania prawdopodobieństwa klinicznej skuteczności terapii empirycznej kandydozy błony śluzowej jamy ustnej dla podstawowych leków przeciwgrzybiczych na podstawie analizy profilu lekowrażliwości wyizolowanych szczepów grzybów drożdżopodobnych.

\section{Materiał i metody}

Materiał badawczy stanowiło 197 pacjentów leczonych w Katedrze i Zakładzie Periodontologii i Chorób Błony Śluzowej Jamy Ustnej GUMed z powodu kandydozy błony śluzowej j. ustnej w latach 2013-2015 (131 kobiet i 66 mężczyzn, w wieku od 26 do 85 lat, średnia wieku $61,4 \pm 13,7$ lat). Analizowano wyniki hodowlanych badań mikologicznych z oznaczeniem antymykogramu uwzględniającego 7 leków. Badania mikologiczne zostały wykonane w Zakładzie Mikrobiologii Jamy Ustnej GUMed - były to standardowe, ogólnodostępne komercyjnie testy, używane rutynowo w klinicznym algorytmie diagnostyczno-terapeutycznym infekcji grzybiczych w obrębie j. ustnej. Materiał z wymazów z błony śluzowej j. ustnej wysiewano 
na agarze Sabourauda i inkubowano w temperaturze $37^{\circ} \mathrm{C}$ od 24 do $48 \mathrm{~h}$ w warunkach tlenowych. Grzyby drożdżopodobne identyfikowano na podstawie: charakterystyki morfologicznej, zdolności formowania chlamydospor, testu filamentacji, charakterystyki wzrostu na podłożach chromogennych (CHROMagarTM Candida, bioMeriéux) oraz testów biochemicznych (API 20 C AUX, bioMeriéux). Badanie lekowrażliwości przeprowadzano z użyciem techniki mikrorozcieńczeń w bulionie (zestaw Fungitest ${ }^{\mathrm{TM}}$ Kit, Bio-Rad). Testowano następujące leki przeciwgrzybicze: 5-fluorocytozynę (2 oraz $32 \mu \mathrm{g} / \mathrm{ml}$ ), amfoterycynę B (2 oraz $8 \mu \mathrm{g} /$ $\mathrm{ml})$, mikonazol (0,5 oraz $8 \mu \mathrm{g} / \mathrm{ml})$, ketokonazol $(0,5$ oraz $4 \mu \mathrm{g} / \mathrm{ml}$ ), itrakonazol (8 oraz $64 \mu \mathrm{g} / \mathrm{ml}$ ) oraz flukonazol (8 oraz $64 \mu \mathrm{g} / \mathrm{ml}$ ). Dodatkowo oznaczono lekowrażliwość na nystatynę (100 j.m.) metodą dyfuzji z krążka w agarze. Interpretację testów przeprowadzono zgodnie $\mathrm{z}$ zaleceniami producentów i przedstawiono w postaci określeń: wrażliwy (W), średnio wrażliwy (SW) oraz oporny (O). Uwzględniając przypadki multiinfekcji, oszacowano prawdopodobieństwo klinicznej skuteczności empirycznej terapii kandydozy dla testowanych leków - w badanej grupie chorych, w 3 podgrupach wydzielonych wg wieku (17 osób w wieku $\leqslant 40$ lat, 71 osób w wieku 41-60 lat, 109 chorych w wieku > 60 lat), a także w podgrupie pacjentów użytkujących ruchome akrylowe uzupełnienia protetyczne (141 pacjentów). Szacunki przewidywanej klinicznej skuteczności empirycznego zastosowania leku przedstawiono używając określeń: POZ - efekt kliniczny pozytywny, wszystkie zidentyfikowane patogeny wrażliwe; WPOZ - efekt kliniczny warunkowo pozytywny, jeden lub więcej patogenów średnio wrażliwy, żaden oporny; NEG - efekt kliniczny negatywny, jeden lub więcej patogenów oporny.

\section{Wyniki}

W badanej grupie 197 chorych wyizolowano łącznie 223 szczepy grzybów drożdżopodobnych. W 174 przypadkach zidentyfikowano jeden patogen, w 23 przypadkach była to multiinfekcja - zidentyfikowano dwa lub trzy szczepy. Dane dotyczące częstości izolacji poszczególnych gatunków grzybów drożdżopodobnych w badanej grupie chorych przedstawiono w tabeli 1. Candida albicans był najczęściej izolowanym gatunkiem - 70,4\% wszystkich szczepów. Drugie miejsce w rankingu częstości izolacji przypadło C. glabrata, a trzecie C. tropicalis. Najrzadziej izolowano szczepy Rhodotorula spp. Odsetki szczepów wrażliwych (W), średnio wrażliwych (SW) oraz opornych $(\mathrm{O})$ wobec badanych substancji przeciwgrzybiczych zaprezentowano w tabeli 2. Najczęściej izolowany ga-
Tabela 1. Częstość izolacji gatunków grzybów drożdżopodobnych w badanej grupie chorych

Table 1. Occurrence frequency for yeast-like fungi

\begin{tabular}{|l|c|c|}
\hline \multicolumn{1}{|c|}{ Gatunek } & $\begin{array}{c}\text { Liczba wyizolowa- } \\
\text { nych szczepów }\end{array}$ & $\begin{array}{c}\text { Odsetek wyizolo- } \\
\text { wanych szczepów }\end{array}$ \\
\hline Candida albicans & 157 & $70,40 \%$ \\
\hline Candida glabrata & 22 & $9,87 \%$ \\
\hline Candida tropicalis & 14 & $6,28 \%$ \\
\hline Candida parapsilosis & 7 & $3,14 \%$ \\
\hline Candida guilliermondii & 6 & $2,69 \%$ \\
\hline Candida krusei & 6 & $2,69 \%$ \\
\hline Geotrichum candidum & 6 & $2,69 \%$ \\
\hline Rhodotorula spp. & 5 & $2,24 \%$ \\
\hline tącznie & 223 & $100 \%$ \\
\hline
\end{tabular}

tunek - C. albicans - charakteryzował się wysoką wrażliwością na testowane leki. Amfoterycynę B należy określić jako lek potencjalnie najefektywniejszy - jedynie 4,46\% szczepów wykazywało lekooporność. Nieznacznie gorszą efektywność oszacowano dla nystatyny $-8,28 \%$ szczepów było opornych.

Spośród zidentyfikowanych gatunków grzybów najwyższą lekooporność zanotowano dla szczepów C. guilliermondii, C. krusei oraz C. glabrata.

Szacunki prawdopodobieństwa efektywności terapii empirycznej zakażenia grzybiczego z użyciem testowanych leków przedstawiono $w$ tabeli 3. Jeśli wziąć po uwagę ogół wyizolowanych szczepów, amfoterycyna B oraz nystatyna charakteryzowały się najwyższym prawdopodobieństwem efektywności klinicznej. Potencjalny efekt leczenia pochodnymi imidazolu i triazolu w ordynacji empirycznej należy określić jako mniej przewidywalny. Terapia flukonazolem byłaby nieskuteczna aż w 29,44\% przypadków, inne pochodne azolowe w około $1 / 4$ przypadków (podczas gdy amfoteryczna B tylko u 5,58\%, a nystatyna u 9,14\% pacjentów). Ryzyko nieskuteczności terapii empirycznej wzrasta w grupie chorych w wieku ponad 60 lat. Ryzyko nieskuteczności terapii empirycznej najpowszechniej stosowanymi lekami azolowymi wzrasta w grupie chorych użytkujących ruchome uzupełnienia protetyczne.

\section{Omówienie wyników i dyskusja}

Gatunek Candida albicans jest najczęściej izolowanym patogenem spośród grzybów drożdżopodobnych, stanowi główny czynnik etiologiczny kandydozy wszystkich typów - w tym także zakażeń o charakterze ogólnoustrojowym. Jego rozpowszechnienie oraz dominująca rola w etiopatogenezie tego typu infekcji są potwierdzone wynikami wielu badań epidemiologicznych na całym świecie [1, 2, 9, 10, 14], w tym również w Polsce [3, 15, 16]. 


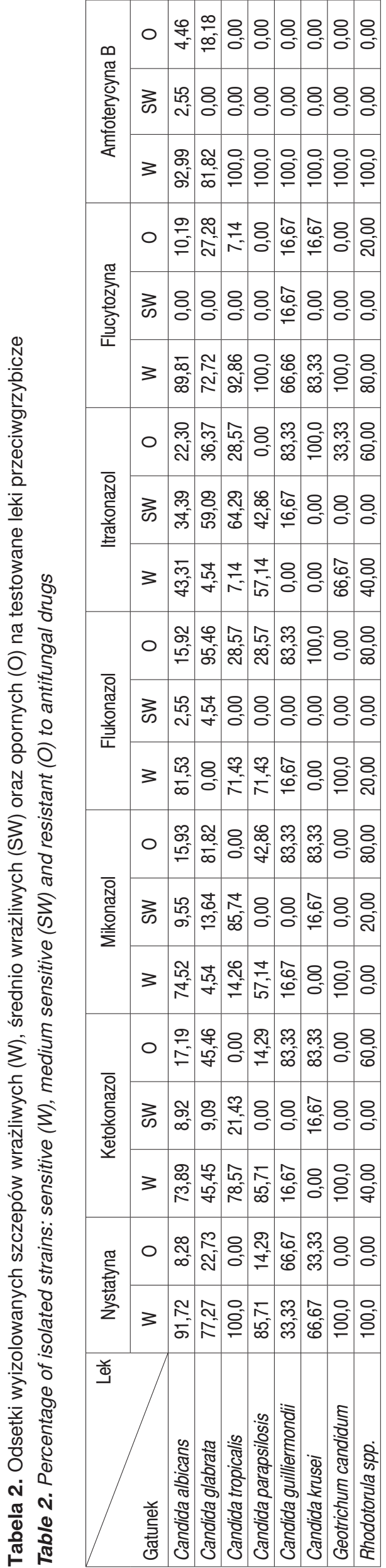

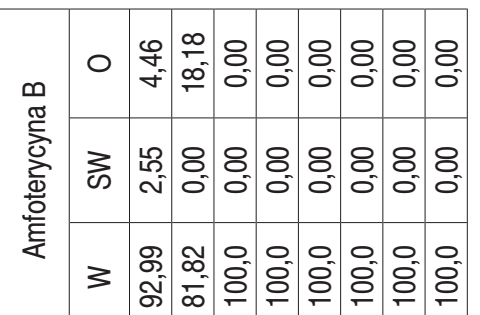

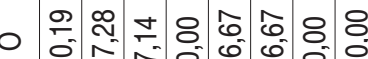

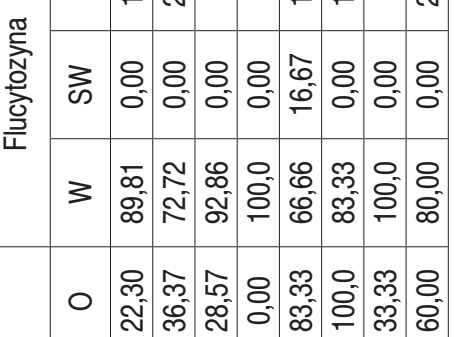

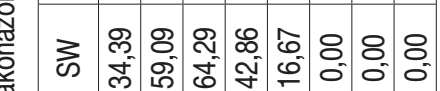

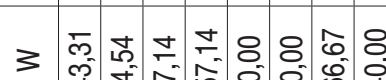

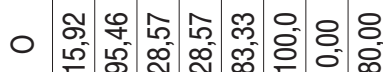

苋 命

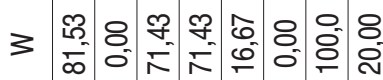

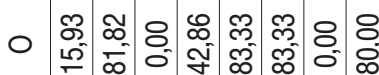

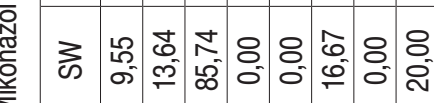

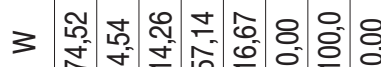

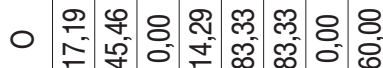

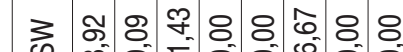

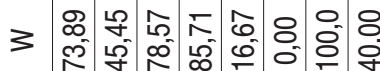

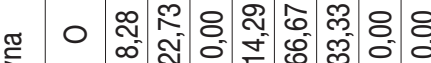

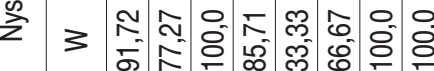

产

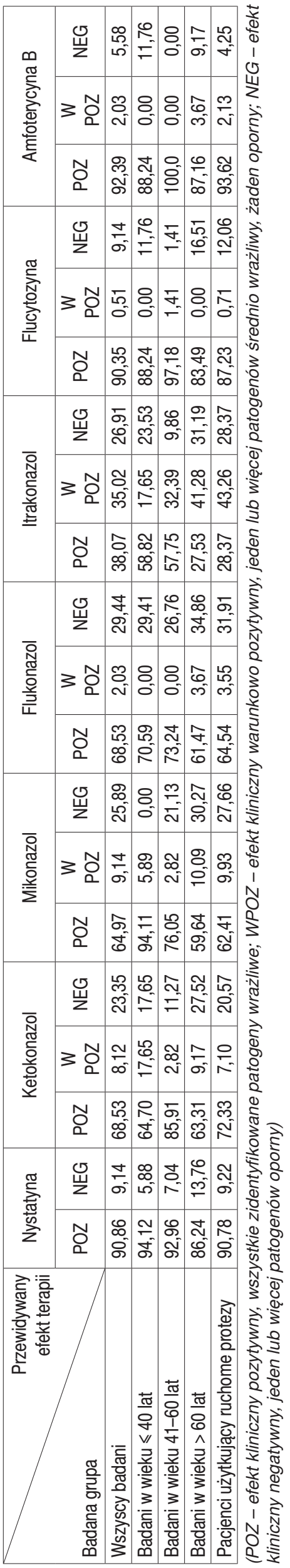


Spośród 1090 szczepów Candida wyizolowanych z próbek krwi w Szwajcarii 61,9\% zidentyfikowano jako $C$. albicans, $17,5 \%$ jako $C$. glabrata, $5,9 \%$ jako C. tropicalis oraz $5,4 \%$ jako C. parapsilosis. Te cztery gatunki łącznie odpowiadały za ponad $90 \%$ przypadków kandidemii [17]. Zbliżone obserwacje poczyniono $w$ analizie fungemii zdiagnozowanych w Niemczech [2]. Analiza różnic w częstości izolacji Candida spp. między rokiem 1997 a 2007 ujawniła, że częstość izolacji $C$. albicans zmniejszała się (70,9\% vs $65,3 \%$ wszystkich szczepów), podczas gdy równolegle wzrastały odsetki identyfikacji gatunków innych niż $C$. albicans (tzw. non-albicans) - C. glabrata, tropicalis i parapsilosis, a częstość izolacji rzadkich gatunków Candida nie wykazywała istotnych zmienności [9]. Zbliżone spektrum gatunków $z$ dominacją $C$. albicans odnotowuje się w wymazach z błony śluzowej j. ustnej. Belazi i wsp. wyizolowali $C$. albicans w $77 \%$ przypadków kandydozy j. ustnej u pacjentów z objawami mucositis oraz kserostomii po radioterapii w obrębie głowy i szyi [1]. Kubicka-Musiał i wsp. potwierdzili obecność C. albicans aż u 78\% chorych z zespołem pieczenia jamy ustnej [15]. Wyższe odsetki potencjalnie bardziej lekoopornych gatunków (jak C. glabrata oraz C. krusei) często są wykrywane w przypadku infekcji grzybiczych błony śluzowej u osób w podeszłym wieku, u chorych z niedoborami odporności, a także pacjentów użytkujących ruchome uzupełnienia protetyczne. W analizie Jaworskiej i wsp. w grupie pacjentów z grzybiczą stomatopatią protetyczną tylko $57,58 \%$ szczepów stanowiły szczepy $C$. albicans. Kolejne miejsca w rankingu częstości izolacji przypadły kolejno: $C$. tropicalis, C. glabrata oraz C. krusei [16]. W wynikach uzyskanych przez Borg-von Zepelin i wsp. wśród 561 przypadków infekcji Candida w 58,2\% zidentyfikowano $C$. albicans, natomiast w prawie $1 / 5$ przypadków patogenem wiodącym był $C$. glabrata [2]. C. albicans jest gatunkiem Candida o największej lekowrażliwości na antymykotyki; leki polienowe powinny wykazywać dużą skuteczność w leczeniu miejscowym. Spośród leków azolowych jako najlepszą alternatywę można wskazać mikonazol - stosowany zarówno w terapii miejscowej, jak i ogólnoustrojowej [12]. Obok danych potwierdzających rzadko występującą lekooporność $C$. albicans opublikowano kilka obserwacji z odmiennymi wnioskami. Zanotowano wzrost lekooporności tego gatunku izolowanego u tych samych osób podczas okresowych wizyt w ciągu 12 miesięcy [18]. Miskiewicz i wsp. zaobserwowali $100 \%$ oporność na flukonazol oraz $83,3 \%$ oporność na ketokonazol wśród szczepów $C$. albicans izolowanych z płyt protez [19]. Większość publikacji wskazuje na zwiększone ryzyko lekooporności wśród gatunków non-albicans. Warto podkreślić znaczącą różnicę w oporności na flukonazol, który ponadto $w$ wielu badaniach wykazuje oporność krzyżową z innymi lekami przeciwgrzybiczymi [11, 20]. Candida glabrata wydaje sie być jednym z najważniejszych patogenów w grupie non-albicans klasyfikowany jest na drugim bądź trzecim miejscu w rankingu częstości izolacji z błony śluzowej j. ustnej $[10,16]$. W ostatnich latach C. glabrata stał się istotnym czynnikiem patologicznym infekcji grzybiczych u chorych z upośledzeniem odporności oraz u chorych z nowotworami okolicy głowy i szyi - zarówno jako patogen pojedynczo izolowany, jak i składnik koinfekcji [6, 21, 22]. Badania z 2014 roku przeprowadzone w Polsce wskazały C. glabrata jako patogen dominujący w inwazyjnych kandydozach (44\% przypadków) [23]. Porównując ten gatunek z $C$. albicans, należy podkreślić jego wyższe zdolności adhezji do powierzchni protez i tym samym potencjalne trudności w eliminacji podczas terapii. C. glabrata charakteryzuje się szerokim spektrum naturalnych oraz nabytych mechanizmów lekooporności, jest w sposób wrodzony oporny na wiele leków, a także substancji stanowiących elementy niespecyficznej odporności przeciwgrzybiczej gospodarza, skutecznych wobec innych szczepów Candida [24, 25]. Wielu autorów opisuje zmniejszoną wrażliwość $C$. glabrata wobec pochodnych azolowych [9, 20, 2628], w szczególności flukonazolu - w analizach około 20 - 30\% szczepów C. glabrata demonstruje oporność lub znacznie zmniejszoną wrażliwość na flukonazol, wraz ze zróżnicowaną opornością krzyżową na inne pochodne triazolowe, co znalazło odzwierciedlenie także w wynikach naszych badań $[7,11,29,30]$. Wśród nowszych pochodnych triazolowych jedynie worykonazol zachowuje dużą skuteczność wobec tego gatunku [29]. C. glabrata może być ponadto naturalnie mniej wrażliwy na amfoterycynę $B$, aczkolwiek w niektórych badaniach odnotowano 100\% wrażliwość (w naszych badaniach $81,82 \%$ wrażliwych szczepów) [11, 22]. Wysoka oporność na antymykotyki azolowe oraz ewentualna potencjalna oporność na amfoterycynę B są powodem rekomendacji stosowania nystatyny jako leku pierwszego rzutu w eliminacji $C$. glabrata. Wyniki badań wskazały także wysoką lekooporność szczepów $C$. krusei. W przeciwieństwie do pochodnych azolowych tylko amfoterycyna B pozostała bardzo efektywnym lekiem. Wyniki 10-letnich badań potwierdzają stały, wysoki (niemal $80 \%$ ) poziom oporności C. krusei na flukonazol [9].

Candida tropicalis oraz parapsilosis często są postrzegane jako gatunki o małej lekooporności. W naszej analizie szczepy w/w gatunków upla- 
sowały się pomiędzy lekowrażliwym C. albicans a zdecydowanie bardziej lekoopornymi $C$. glabrata, krusei oraz guilliermondii. latta i wsp, w oparciu o dokumentację 320 przypadków kandidemii, odnotowali istotną redukcję wrażliwości $C$. tropicalis na flukonazol [27]. Opublikowano także doniesienia o niewielkim wzroście oporności na flukonazol wśród szczepów C. parapsilosis [9]. W badaniach własnych stwierdzono bardzo wysoki odsetek lekoopornych szczepów C. guilliermondii - 83,33\% szczepów charakteryzowało się opornością na flukonazol. Wartość ta różni się od danych uzyskanych w programie badawczym ARTEMIS DISK, podczas którego odnotowano odsetki lekooporności na flukonazol na poziomie $11,4-26,5 \%$. Worykonazol jest często wskazywany jako lek skuteczny wobec szczepów $C$. guilliermondii opornych na inne leki przeciwgrzybicze [9, 31].

Leczenie infekcji grzybiczych błony śluzowej jamy ustnej jest złożonym procesem. Wymaga postawienia właściwej diagnozy, rozpoznania gatunku grzyba związanego etiologicznie z objawami klinicznymi oraz określenia profilu jego lekowrażliwości / lekooporności. Istotna jest właściwa identyfikacja oraz eliminacja (ew. redukcja) czynników predysponujących do infekcji, zarówno ogólnoustrojowych (np. właściwa kontrola glikemii u chorego z cukrzycą), jak i miejscowych (np. zwalczanie współistniejącej kserostomii). Należy dokonać wyboru pomiędzy terapią miejscową a ogólnoustrojową, a następnie wybrać najwłaściwszy lek przeciwgrzybiczy, najlepiej w oparciu o profil lekowrażliwości patogenu, z uwzględnieniem toksyczności, działań niepożądanych, przeciwwskazań oraz możliwych interakcji. Dodatkowo należy rozważyć użycie miejscowe dodatkowych substancji o działaniu przeciwgrzybiczym, np. roztworu chlorheksydyny - szczególnie u pacjentów użytkujących ruchome uzupełnienia protetyczne $[32,33]$. Sukces terapeutyczny wymaga przestrzegania właściwego czasu terapii i uzyskania dobrej współpracy pacjenta. Bardzo ważna jest profilaktyka nawrotów schorzenia, ze szczególnym podkreśleniem prawidłowego leczenia protetycznego, instruktażu oraz kontroli higieny jamy ustnej i protez oraz znaczenia okresowych wizyt kontrolnych.

Optymalny wybór celowanego leku przeciwgrzybiczego powinien bazować na profilu lekowrażliwości patogenu. Wytyczne dla oznaczania antymykogramów są publikowane przez European Committee on Antibiotic Susceptibility Testing (EUCAST). Technika użyta w niniejszym badaniu (komercyjnie dostępny zestaw Fungitest ${ }^{\mathrm{TM}}$ Kit, Bio-Rad) opisywana jest jako jedna z najszybszych, a zarazem bardzo wiarygodnych alternatyw $[11,34]$. W USA podobne standardy są prezento- wane przez Clinical and Laboratory Standards Institute (CLSI). Obie instytucje systematycznie uaktualniają wytyczne, a ich standardy są uważane za równorzędne i prowadzące do zbliżonych wyników [17, 35, 36]. Tym niemniej niektórzy badacze podkreślają trudności w bezpośrednim porównaniu danych dotyczących lekooporności, które oznaczano używając różnych technik oraz interpretowano według konkurencyjnych standaryzacji wartości stężeń granicznych leków [34]. W przypadku przeciwgrzybiczej terapii empirycznej, aby uzyskać najlepsze rezultaty kliniczne, należy przestrzegać aktualnych zaleceń i algorytmów. W większości przypadków infekcji grzybiczych błony śluzowej j. ustnej terapię miejscową należy uznać za terapię pierwszego rzutu [6, 7, 37-39]. Nystatyna jest rekomendowana wśród leków pierwszego wyboru w niepowikłanych zakażeniach grzybiczych obszaru j. ustnej i gardła w wytycznych Infectious Diseases Society of America (IDSA) [37-39]. Także większość rekomendacji polskich postuluje ogólnoustrojową ordynację antymykotyków wyłącznie w sytuacji niepowodzenia leczenia miejscowego [8]. Nystatyna w postaci zawiesiny wydaje się być jedną z najlepszych opcji - patogeny są w dużym stopniu wrażliwe, lek jest powszechnie znany i dostępny. Terapia charakteryzuje się wysokim bezpieczeństwem z minimalnym ryzykiem działań niepożądanych. Ryzyko interakcji z innymi lekami (co jest częstym problemem podczas przyjmowania leków azolowych) jest niewielkie wskutek znikomych ogólnoustrojowych stężeń leku (braku wchłanialności z przewodu pokarmowego). Za wadę nystatyny należy uznać konieczność uzyskania dobrej współpracy pacjenta - leczenia trwa stosunkowo długo (nawet do 6 tygodni), a lek musi być aplikowany kilka razy na dobę. Pacjenci rzadko zgłaszają objawy nietolerancji leku związane $z$ dyskomfortem w j. ustnej. Przeciwgrzybicze leki aplikowane miejscowo mogą wykazywać również skuteczność w zwalczaniu nadkażenia akrylowych uzupełnień protetycznych, względnie ruchomych aparatów ortodontycznych - ich kliniczna efektywność w leczeniu stomatopatii protetycznych związanych z kandydozą znajduje odzwierciedlenie w literaturze [28, 32]. Amfoterycyna B - lek o potencjalnie dużych możliwościach klinicznych - nie jest dostępny w postaci do stosowania miejscowego w wielu krajach, również w Polsce. Procedury importu docelowego nie stanowią realnej alternatywy $w$ codziennej pracy stomatologów. Amfoterycyna B w postaciach dożylnych powinna być używana jedynie w przypadkach niepowodzeń standardowych opcji terapeutycznych i jest zwykle ograniczona do lecznictwa zamkniętego. Należy zaakcentować wiele potencjalnych obja- 
wów niepożądanych i wysoką toksyczność tego leku, szczególnie nefrotoksyczność. Trzecim lekiem z grupy antybiotyków polienowych jest natamycyna. W wielu podręcznikach z zakresu chorób błony śluzowej j. ustnej podkreślono jej wysoką skuteczność w terapii miejscowej (roztwór 2,5\% Pimafucin ${ }^{\circledast}$ ). Niestety w chwili obecnej brak odpowiedniego leku w ofercie polskiego rynku farmaceutycznego. Dostępne postacie natamycyny są zarezerwowane do leczenia infekcji ginekologicznych, względnie skórnych - postać kremu może mieć znaczenie tylko w terapii grzybiczego zapalenia kątów ust. Na niektórych rynkach europejskich natamycyna jest dostępna w postaci tabletek do ssania. Alternatywą dla leków polienowych w terapii miejscowej jest mikonazol, który często wykazuje aktywność wobec szczepów Candida spp. opornych na flukonazol [21]. Nowo opracowany system administracji leku - tabletki dopoliczkowe - jest opisywany jako dobrze tolerowany i skuteczniejszy od podstawowej formy miejscowej - żelu [39-41]. Nowoczesna forma dystrybucji leku wiąże się z aplikacją tabletki raz na dobę, co w znaczący sposób poprawia stopień współpracy pacjenta, szczególnie w porównaniu z częstą aplikacją nystatyny. Podczas miejscowego stosowania mikonazolu obserwowano tylko niewielką ogólnoustrojową absorbcję leku [41]. Szacunkowe ryzyko nieskuteczności mikonazolu w terapii empirycznej w naszych badaniach obliczono na 25,89\%, w grupie osób użytkujących ruchome uzupełnienia protetyczne odsetek ten był jeszcze wyższy - 30,27\%. W podobnej analizie przeprowadzonej w Wielkiej Brytanii i we Włoszech w 21\% przypadków wyizolowane szczepy były oporne na ten lek [11].

Przegląd literatury dotyczącej lokalnej terapii kandydozy pokazuje duże zróżnicowanie postulowanych schematów terapeutycznych i uzyskiwanych efektów leczenia. Niehomogenna metodologia wielu badań czyni ich bezpośrednie porównanie, a tym bardziej formułowanie ogólnych wniosków, bardzo trudnym. Publikowane wytyczne terapeutyczne również spotykają się z polemiką [12, 42, 43].

Flukonazol jestnajczęściej przepisywanymogólnoustrojowym lekiem przeciwgrzybiczym w terapii zakażeń błon śluzowych. W wielu rekomendacjach uznawany jest za lek pierwszego rzutu - między innymi w wytycznych IDSA dla leczenia średnio ciężkich i ciężkich postaci kandydozy j. ustnej, a także leczeniu grzybiczych infekcji oportunistycznych związanych z zakażeniem HIV [4, 14, 37-39]. Niektóre doniesienia potwierdzają dużą skuteczność flukonazolu w terapii candidosis mucosae oris z niskim ryzykiem rozwoju lekooporności in vitro [4].
W dużym kontraście do tych stwierdzeń pozostaje wiele wyników badań, które stwierdzają w ciągu ostatniej dekady ciągły wzrost częstości szczepów opornych wobec tego leku [24, 29], co może być związane jego powszechnym nadużywaniem. Potwierdzono ryzyko zależności pomiędzy podażą flukonazolu a długoterminowym wzrostem rozwoju lekooporności $C$. albicans u pacjentów ze stomatopatią protetyczną [44]. Wśród gatunków non-aIbicans wzrost odsetków szczepów z wrażliwością zależną od dawki zmusza do stosowania wyższych dawek flukonazolu [29]. Niektórzy autorzy postuluja ograniczenie stosowania flukonazolu wyłącznie do przypadków niepowodzenia terapii miejscowej lub sytuacji wymagających niezwłocznego wdrożenia leczenia ogólnoustrojowego [6]. W oparciu o wyniki niniejszych badań skłaniamy się ku poparciu powyższego postulatu - w naszym materiale klinicznym empiryczne zlecanie terapii flukonazolem byłoby dość ryzykowne - nieskuteczne w prawie 1/3 przypadków.

Warto zwrócić uwagę również na skrócenie standardowego czasu terapii oraz brak możliwości bezpośredniego oddziaływania leku na płytę protezy. Dlatego oczekiwana skuteczność leków stosowanych miejscowo powinna być wyższa, ale należy zawsze mieć na uwadze, że nie dotyczy to przypadków, w których niemożliwa będzie dobra współpraca z pacjentem - na co zwracają uwage Goins i wsp. [45]. Ryzyko empirycznego stosowania farmaceutyku rośnie istotnie wśród chorych powyżej 60 roku życia, co koresponduje z częstszą izolacją flukonazolo-opornych gatunków. Aktualne rekomendacje nie zalecają doustnego stosowania ketokonazolu z powodu wysokiego prawdopodobieństwa ciężkich efektów niepożądanych - przede wszystkim efektów hepatotoksycznych [46]. Lek ten został wycofywany z rynków farmaceutycznych wielu krajów, także w Polsce. W publikacjach pozytywnie oceniany bywa klotrimazol w postaci nowo wprowadzonej formy terapii miejscowej - lakieru o przedłużonym uwalnianiu leku oraz tabletek do ssania [47]. Lek ten polecany jest w najnowszych wytycznych IDSA w łagodnych postaciach infekcji [39]. Omawiając uzyskane wyniki badań należy zauważyć istotny odsetek szczepów Candida o obniżonej wrażliwości na itrakonazol - ok. $60 \%$. Gatunki C. krusei i C. guilliermondii były oporne w największym stopniu. Zmniejszoną wrażliwość na ten lek potwierdzają badacze niemieccy [2] oraz włoscy [11]. W wytycznych IDSA itrakonazol nie jest zaliczany do leków pierwszego rzutu w terapii candidosis - jest rekomendowany jako lek alternatywny, szczególnie w przypadku oporności na flukonazol [37, 39]. Posakonazol - jeden z najnowszych leków triazolowych o po- 
szerzonym spektrum - ma potencjalną aktywność wobec szczepów opornych na flukonazol i itrakonazol. Stanowi bezpieczną i skuteczną opcję terapeutyczną, szczególnie u pacjentów zakażonych HIV z nawrotową kandydozą j. ustnej i gardła $[39,48]$. Flucytozyna (5-fluorocytozyna) wykazała w naszych obserwacjach dobrą aktywność wobec szczepów Candida. Potwierdzają to wyniki innych badań [11]. Natomiast znaczenie tego leku w stomatologicznej praktyce klinicznej jest ograniczone, a część doniesień wskazuje na szybki rozwój lekooporności w trakcie terapii [24].

Należy podsumować, że terapia empiryczna lekami polienowymi wydaje się być bardziej przewidywalna niż użycie pochodnych azolowych. W szczególny sposób dotyczy to chorych starszych, u których częściej izolowane są gatunki lekooporne. U osób z grup ryzyka należy dążyć do wdrażania celowanej terapii przeciwgrzybiczej [14]. Należy jednak także mieć na uwadze fakt, że określenie lekowrażliwości in vitro nie zawsze musi korelować ze skuteczną odpowiedzią pacjenta na zastosowane leczenie. Efekt terapii jest bowiem wypadkową zależności pomiędzy odpornością gospodarza, aktywnością i biodynamiką leku oraz właściwościami biologicznymi patogenu. Dodatkowych trudności spodziewamy się ponadto $w$ leczeniu stomatopatii protetycznych - biofilm z udziałem szczepów Candida prezentuje zawsze wyższą lekooporność w porównaniu z formą planktoniczną [25, 44, 49, 50].

\section{Wnioski}

1. Najczęściej izolowany gatunek - Candida albicans - prezentował niską lekooporność wobec testowanych leków.

2. Najwyższą lekooporność odnotowano wśród szczepów Candida guilliermondii, C. krusei oraz C. glabrata.

3. Amfoterycyna B oraz nystatyna charakteryzowały się najwyższym prawdopodobieństwem klinicznej skuteczności.

4. Pochodne azolowe należy określić jako leki mniej przewidywalne w empirycznej terapii kandydozy błony śluzowej jamy ustnej.

5. Ryzyko nieskuteczności terapii empirycznej wzrasta w grupie pacjentów powyżej 60 roku życia.

\section{Oświadczenia}

\section{Oświadczenie dotyczące konfliktu interesów}

Autorzy deklarują brak konfliktu interesów w autorstwie oraz publikacji pracy.

\section{Źródła finansowania}

Autorzy deklarują brak źródeł finansowania.

\section{Piśmiennictwo}

[1] Belazi M, Velegraki A, Koussidou-Eremondi T, Andreadis D, Hini S, Arsenis G, Eliopoulou C, Destouni E, Antoniades $D$. Oral Candida isolates in patient undergoing radiotherapy for head and neck cancer: prevalence, azole susceptibility profiles and response to antifungal treatment. Oral Microbiol Immunol. 2004;19:347-351.

[2] Borg-von Zepelin M, Kunz L, Rüchel R, Reichard U, Weig M, Gross U. Epidemiology and antifungal susceptibilities of Candida spp. to six antifungal agents: results from a surveillance study on fungaemia in Germany from July 2004 to August 2005. J Antimicrob Chemother. 2007;60:424-428.

[3] Kozłowski Z, Konopka T, Karolewska E, Mendak M. Częstość występowania infekcji jamy ustnej grzybami z rodzaju Candida u pacjentów stomatologicznych. Mikol Lek. 2007;14:169-172.

[4] Kuriyama T, Williams DW, Bagg J, Coulter WA, Ready D, Lewis MA. In vitro susceptibility of oral Candida to seven antifungal agents. Oral Microbiol Immunol. 2005;20:349_ 353.

[5] Krawiecka E, Jankowski M, Kryś J, Radecka M, Smoczyńska-Marczak M, Piotrowska I, Szponar E. Ocena stanu jamy ustnej i występowania Candida u ogólnie zdrowych polskich i zagranicznych studentów stomatologii. Dental Forum. 2013;XXXXI:21-25.

[6] Bensadoun RJ, Patton LL, Lalla RV, Epstein JB. Oropharyngeal candidiasis in head and neck cancer patients treated with radiation: update 2011. Support Care Cancer. 2011;19:737-744.

[7] Ruhnke M, Rickerts V, Cornely OA, Buchheidt D, Glöckner A, Heinz W, Höhl R, Horré R, Karthaus M, Kujath P, Willinger B, Presterl E, Rath P, Ritter J, Glasmacher A, Lass-Flörl C, Groll A. Diagnosis and therapy of Candida infections: joint recommendations of the German Speaking Mycological Society and the Paul-Ehrlich-Society for Chemotherapy. Mycoses. 2011;54:279-310.

[8] Biliński P, Seferyńska I, Warzocha K. Diagnostyka i leczenie układowych zakażeń grzybiczych w onkohematologii. Onkol Prak Klin. 2008;4:45-24.

[9] Pfaller MA, Diekema DJ, Gibbs DL, Newell VA, Ellis D, Tullio V, Rodloff A, Fu W, Ling TA. Results from the ARTEMIS DISK Global Antifungal Surveillance Stud. 1997 to 2007: a 10.5-year analysis of susceptibilities of Candida species to fluconazole and voriconazole as determined by CLSI standardized disk diffusion. J Clin Microbiol. 2010;48(4):1366-1377.

[10] Pfaller MA, Moet GJ, Messer SA, Jones RN, Castanheira M. Geographic variations in species distribution and echinocandin and azole antifungal resistance rates among Candida bloodstream infection isolates: report from the SENTRY Antimicrobial Surveillance Program (2008 to 2009). J Clin Microbiol. 2011;49:396-399.

[11] Manfredi M, McCullough MJ, Polonelli L, Conti S, Al-Karaawi $Z M$, Vescovi $P$, Porter $S R$. In vitro antifungal susceptibility to six antifungal agents of 229 Candida isolates from patients with diabetes mellitus. Oral Microbiol Immun. 2006;21:177-182.

[12] Garcia-Cuesta C, Sarrion-Perez MG, Bagan JV. Current treatment of oral candidiasis: A literature review. J Clin Exp Dent. 2014;6:e576-582.

[13] Staniszewska M, Bondaryk M, Kowalska M, Magda U, Łuka M, Ochal Z, Kurzątkowski W. Patogeneza i leczenie zakażeń Candida spp. Post Mikrobiol. 2014;53:229-240.

[14] Brito GN, Inocencio AC, Querido SM, JorgE AO, Koga-Ito CY. In vitro antifungal susceptibility of Candida spp. oral isolates from HIV-positive patients and control individuals. Braz Oral Res. 2010;25:28-33.

[15] Kubicka-Musiał M, Musiał S, Wierucka-Młynarczyk B, Hüpsch-Marzec H. Częstość występowania infekcji grzybiczej oraz ocena lekowrażliwości grzybów z rodzaju Candida u pacjentów z objawami pieczenia błony śluzowej jamy ustnej. Dent Med Probl. 2011;48(3):364-370. 
[16] Jaworska-Zaremba M, Mierzwińska-Nastalska E, Swoboda-Kopeć E, Gierkowska J. Ocena wrażliwości grzybów drożdżopodobnych izolowanych w stomatopatiach protetycznych na wybrane, naturalne preparaty o działaniu przeciwgrzybiczym. Protet Stomatol. 2012;LXII:390-399.

[17] Orasch C, Marchetti O, Garbino J, Schrenzel J, Zimmerli S, Mühlethaler K, Pfyffer G, Ruef C, Fehr J, Zbinden $\mathrm{R}$, Calandra T, Bille J. Candida species distribution and antifungal susceptibility testing according to European Committee on Antimicrobial Susceptibility Testing and new vs. old Clinical and Laboratory Standards Institute clinical breakpoints: a 6-year prospective candidaemia survey from the fungal infection network of Switzerland. Clin Microbiol Infect. 2014;20:698-705.

[18] Samaranayake YH, Samaranayake LP, Tsang PC, Wong $\mathrm{KH}$, Yeung KW. Heterogeneity in antifungal susceptibility of clones of Candida albicans isolated on single and sequential visits from HIV-infected southern Chinese cohort. J Oral Pathol Med. 2001;30:336-346.

[19] Miskiewicz A, Szparecki G, Nowak M, Górska R. Analiza epidemiologiczna występowania Candida species oraz ich lekooporności u pacjentów ze stomatopatią protetyczną. Nowa Stomatologia. 2013;3:141-144.

[20] Panackal AA, Gribskov JL, Staab JF, Kirby KA, Rinaldi $M$, Marr KA. Clinical significance of azole antifungal drug cross-resistance in Candida glabrata. J Clin Microbiol. 2006;44(5):1740-1743.

[21] Isham N, Ghannoum MA. Antifungal activity of miconazole against recent Candida strains. Mycoses. 2009;53:434-437.

[22] Yamashita K, Ohara M, Kojima T. Prevalence of drug-resistant opportunistic microorganisms in oral cavity after treatment for oral cancer. J Oral Sci. 2013;55:145155

[23] Gołaś M, Netsvyetayeva I, Sikora M, Piskorska K, Sulik-Tyszka B, Swoboda-Kopeć E. Trends in antifungal susceptibility of Candida species - one year observation. Pol J Microbiol. 2014;63:217-222.

[24] Sanglard D, Odds FC. Resistance of Candida species to antifungal agents: molecular mechanisms and clinical consequences. Lancet Infect Dis. 2002;2:73-85.

[25] Konopka K, Dorocka-Bobkowska B, Gebremedhin S, Düzgüneş N. Susceptibility of Candida biofilms to histatin 5 and fluconazole. Antonie Van Leeuwenhoek. 2010;97:413-7.

[26] Li L, Redding S, Dongari-Bagtzoglou A. Candida glabrata, an emerging oral opportunistic pathogen. J Dent Res. 2007;86:204-215.

[27] latta R, Caggiano G, Cuna T, Montagna MT. Antifungal susceptibility testing of a 10-year collection of Candida spp. isolated from patients with candidemia. J. Chemother. 2011;23:92-96.

[28] Dorocka-Bobkowska B, Konopka K. Susceptibility of candida isolates from denture-related stomatitis to antifungal agents in vitro. Int J Prosthodont. 2007;20:504-6.

[29] Ruan SY, Chu CC, Hsueh PR. In vitro susceptibilities of invasive isolates of Candida species: rapid increase in rates of fluconazole susceptible-dose dependent Candida glabrata isolates. Antimicrob Agents Chemother. 2008;52(8):2919-2922.

[30] Rodloff AC, Koch D, Schaumann R. Epidemiology and antifungal resistance in invasive candidiasis. Eur J Med Res. 2011:16:187-195.

[31] Pfaller MA, Diekema DJ, Mendez M, Kibbler C, Erzsebet P, Chang SC, Gibbs DL, Newell VA. Candida guilliermondii, an opportunistic fungal pathogen with decreased susceptibility to fluconazole: geographic and temporal trends from the ARTEMIS DISK antifungal surveillance program. J Clin Microbiol. 2006;44:3551-3556.

[32] Webb BC, Thomas CJ, Willcox MD, Harty DW, Knox KW. Candida-associated denture stomatitis. Aetiology and management: A review. Part 3. Treatment of oral candidosis. Aust Dent J. 1998;43(4):244-250.

[33] Bondaryk M, Kurzątkowski W, Staniszewska M. Antifungal agents commonly used in the superficial and mucosal candidiasis treatment: mode of action and resistance development. Post Derm Alergol. 2013;30:293-301.

[34] Cuenca-Estrella M, Gomez-Lopez A, Mellado E, Rodriguez-Tudela JL. Correlation between the procedure for antifungal susceptibility testing for Candida spp. of the European Committee on Antibiotic Susceptibility Testing (EUCAST) and four commercial techniques. Clin Microbiol Infect. 2005;11:486-492.

[35] Fothergill AW, Sutton DA, Mccarthy DI, Wiederhold NP. Impact of new antifungal breakpoints on antifungal resistance in Candida species. J Clin Microbiol. 2014;52: 994-997.

[36] Pfaller MA, Castanheira M, Messer SA, Rhomberg PR, Jones RN. Comparison of EUCAST and CLSI broth microdilution methods for the susceptibility testing of 10 systemically active antifungal agents when tested against Candida spp. Diagn Microbiol Infect Dis. 2014;79(2):198-204.

[37] Pappas PG, Rex JH, Sobel JD, Filler SG, Dismukes WE, Walsh TJ, Edwards JE. Guidelines for treatment of candidiasis. Clin Infect Dis. 2004;38:3861-189

[38] Pappas PG, Kaufmann CA, Andes D, Benjamin Jr. DK, Calandra TF, Edwards JE, Filler SG, Fisher JF, Kullberg BJ, Ostrosky-Zeichner L, Reboli AC, Rex JH, Walsh TJ, Sobel JD. Clinical practice guidelines for the management of candidiasis: 2009 update by the Infectious Diseases Society of America. Clin Infect Dis. 2009;48:503-535.

[39] Pappas PG, Kauffman CA, Andes DR, Clancy CJ. Marr KA, Ostrosky-Zeichner L, Reboli AC, Schuster MG, Vazquez JA, Walsh TJ, Zaoutis TE, Sobel JD. Clinical practice guideline for the management of candidiasis: 2016 update by the Infectious Diseases Society of America. Clin Infect Dis. 2016;62:e01-50.

[40] Bensadoun RJ, Daoud J, El Gueddari B, Bastit L, Gourmet R, Rosikon A, Allavena C, Céruse P, Calais G, Attali P. Comparison of the efficacy and safety of miconazole $50 \mathrm{mg}$ mucoadhesive buccal tablets with miconazole 500 $\mathrm{mg}$ gel in the treatment of oropharyngeal candidiasis. Cancer. 2008;112:204-211.

[41] Vazquez JA, Sobel JD. Miconazole mucoadhesive tablets: A novel delivery system. Clin Infect Dis. 2012;54:14801484.

[42] Stoopler ET, Sollecito TP. Oral mucosal diseases: evaluation and management. Med Clin North Am. 2014;98:1323-52.

[43] Deshpande A, Gaur S, Bal AM. Candidaemia in the non-neutropenic patient: a critique of the guidelines. Int J Antimicrob Agents. 2013;42:294-300.

[44] Figueiral MH, Fonseca P, Lopes MM, Pinto E, Pereira-Leite T, Sampaio-Maia B. Effect of denture-related stomatitis fluconazole treatment on oral Candida albicans susceptibility profile and genotypic variability. Open Dent $\mathrm{J}$. 2015;30:46-51.

[45] Goins RA, Ascher D,Waecker N, Arnold J, Moorefield E. Comparison of fluconazole and nystatin oral suspensions for treatment of oral candidiasis in infants. Pediatr Infect Dis J. 2002;21:1165-1167.

[46] García Rodríguez LA, Duque A, Castellsague J, Pérez-Gutthann S, Stricker BH. A cohort study on the risk of acute liver injury among users of ketoconazole and other antifungal drugs. Br J Clin Pharmacol. 1999;48(6):847852.

[47] Czerninski R, Sivan S, Steinberg D, Gati I, Kagan L, Friedman M. A novel sustained-release clotrimazole varnish for local treatment of oral candidiasis. Clin Oral Invest. 2010;14:71-78.

[48] Skiest DJ, Vazquez JA, Anstead GM, Graybill JR, Reynes J, Ward D, Hare R, Boparai N, Isaacs R. Posaconazole for the treatment of azole-refractory oropharyngeal and esophageal candidiasis in subjects with HIV infection. Clin Infect Dis. 2007;44:607-614.

[49] Chandra J, Mukherjee PK, Leidich SD, Faddoul FF, Hoyer LL, Douglas LJ, Ghannoum MA. Antifungal resistance of candidal biofilms formed on denture acrylic in vitro. J Dent Res. 2001;80:903-908. 
[50] Taff HT, Mitchell KF, Edward JA, Andes DR. Mechanisms of Candida biofilm drug resistance. Future Microbiol. 2013;8:1325-1337.

Zaakceptowano do edycji: 2017-04-18 Zaakceptowano do publikacji: 2017-04-26
Adres do korespondencji:

Mariusz Bochniak

Katedra i Zakład Periodontologii

i Chorób Błony Śluzowej Jamy Ustnej

Gdański Uniwersytet Medyczny

ul. Orzeszkowej 18, 80-204 Gdańsk

tel./fax: +48 583492178

e-mail: rstep@gumed.edu.pl 